\title{
Lessons from the life of Samson on battling with harassing iniquities
}

\author{
Dr Maxwell Zakhele Shamase \\ Acting Deputy Dean: Teaching and Learning \\ Faculty of Arts \\ University of Zululand, South Africa \\ E-mail: ShamaseM@unizulu.ac.za \\ DOI: https://doi.org/10.46222/pharosjot.102.038
}

\begin{abstract}
The story of Samson one of the Israelite judges emanating from the tribe of Dan, was a Nazirite and it is indeed an intriguing one in the book of Judges. Klein (1988) alerts us that an even superficial reading of the book demonstrates that the epic is far more biographical in nature than any of the earlier chapters tends to be. Samson's sensual attachment to women are they stuff that legends are made of. The last glimpse we have of Samson is of a man who seemed to have put his act together. We earlier saw Samson calling on the Lord in humility. He prayed to God and God ultimately delivered him from death through a great miracle. That story ends with Samson having judged Israel for 20 years. Crenshaw (1978) contends that Samson was indeed one through whom God would "begin to deliver Israel from the hand of the Philistines" (Judges 13:5). However, after a period of peace and steadfast service, Samson sadly falls once again into his old ways. His old passions rise to the surface and Samson once again finds himself entangled in a web of sin. Samson may have been a powerful man physically, but he was to intents and purposes a moral weakling. He may have demonstrated his power time and again over the enemies of the Lord, but he was helpless against the power of his mortal flesh. It also is evident from books preceding Judges, that the wickedness of the Israelites validates Israel's subjugation to the Philistines. Thus, we see that sin is punished and that unrighteous dealings lead a nation or an individual to destruction. As a judge, Samson was invariably unsuccessful in delivering what the Lord required of him and he thus brought destruction on himself (Bar, 2020). This article based on an exegetical methodology considered mainly historical context and it unpacks how failing to serve God ultimately leads to one battling with harassing iniquities which ultimately lead to destruction. It serves as a model of how we ought to seek to serve God in a spirit of obedience.
\end{abstract}

Keywords: Disobedience, adultery, malevolence, spirituality, personal growth.

\section{Introduction}

The saga of Samson, ןשeׁi, "man of the sun" as evidenced in the story described in Judges $13-16$ is indeed enthralling and meaningful for the spiritual growth of believers. Matthews (1989) states that there are sex and violence, powerful women, and a deeply defective hero. Samson was from the tribe of Dan and he was the son of Manoah from the city of Zorah. His mother was infertile but an angel of the Lord appeared to her on two occasions, and informed her and her husband that they would have a son. He advised that their son was to be dedicated to the Lord. Samson served as judge of Israel from 1085 to 1065 BCE and he lived in a period of great social and political turbulence. Israel had no monarch and most people did as they please and were devoid of any moral or ethical stance. Seven times Israel had turned from God and again found themselves under the tyrannical rule of the Philistines who were the remnants of a Cretan civilization, trying to enter Egypt via Asia Minor through Palestine and by sea (Burney, 1930). 
The trend appears to have been that the people of Israel would follow God but then turn to idolatry and spiritual bondage. Once this situation manifested, and they became desperate, they tended to call upon the Lord to deliver them and He, in His grace, would send them a judge to guide them to correct action and place them on the path to salvation. This they did only to soon return to idol worship. In Samson's lifespan, recorded in Judges 13-17, people were slaves under the yoke of Philistine oppression for about four decades. He delivered Israel from their Philistine overlords (Judges13:5). "And again the sons of Israel did evil in the eyes of YHWH and YHWH gave them into the hand of the Philistines (for) forty years" (Judges 13:1) The book thus clearly informs us of the purpose of Samson as a Judge (Crossan, 1968). Comay (1993) refutes any suggestion that Samson was a mere mythological hero and she accepts as true that the biblical story of Samson is so precise regarding time and place, that Samson was incontestably a real person with immense physical power who fought against the Philistines. Zakovitch maintains that the story of Samson's birth in Judges 13 is contingent upon and adjusts the episode relating to the call of Gideon (Judges 6).

When researching the biblical narrative of Samson in its canonical form, whatever its hypothetical history of composition and redaction, nothing should be regarded as secondary or incorporated, everything must be considered as being possibly meaningful and the story must be read in its wider literary context as it transmits various messages to a reader and has latent meanings (Greenstein, 1981). Samson's story is at times is considered as an Israelite variety of the popular Near Eastern folk hero also embodied by the Sumerian Enkidu and the Greek god-man Heracles (Margalith, 1987). Numerous academics construed Samson as being a demigod who made his way into Jewish folklore (Levington, 2014) or even possibly as an archetypical folk hero (Mobley, 2006). Samson's birth was miraculous, and in a similar vein to that of Abraham and Sarah who, like Samson's parents, received an angelic herald before miraculous conceptions occurred. The angel predicted Samson's birth to his mother: "Behold, you are barren and have not borne children, but you shall conceive and bear a son" (Judges 13:5). Later we see an adult Samson leaves the hills of his people to see the towns of Philistia. He falls in love with a Philistine woman from Timnah, and he chooses to marry her, disregarding the many protestations of his parents due to the fact that she is not an Israelite (Singer, 1906). However, the envisioned nuptial is revealed to be part of God's plan to assault the Philistines (Comay \& Brownrigg, 1993).

Samson was however courting insubordination by endeavoring to marry a Philistine woman: "You shall not intermarry with them, giving your daughters to their sons or taking their daughters for your sons, for they would turn away your sons from following me, to serve other gods" (Deuteronomy 7:3-4). Samson replies "Get her for me, for she is right in my eyes" (Judges 14:3). This utterance demonstrates to us Samson's attraction and it divulges his spiritual condition to us so that later he even "...went down and talked with the woman, and she was right in Samson's eyes" (Judges 14:7). During his wedding to the Philistine woman, he was cuckolded and disgraced by his wife and their wedding guests (Judges 14:1-15). Infuriated, Samson sought vengeance and killed 1,000 men (Judges 15:1-20).

Samson reminds us in some ways of Achilles the hero of the siege of Troy (Graves, 2017). According to Greek Mythology, Achilles was the son of a human king named Peleus and a sea goddess named Thetis. Achilles was the greatest, bravest, strongest and most handsome soldier in his father's army (Burgess, 2009). The legend goes that Thetis held her infant son by the heel and dipped him in the waters of the River Styx (Graves, 2017). The magical powers of the river rendered Achilles unassailable in every part of his body, except his heel, which had not been dipped into the river. That small, little part of his flesh was vulnerable to attack. Later, in the heat of battle, Achilles was struck in the heel by an arrow and was killed (Burgess, 2009). That myth has become a proverb by which many live their lives. 
Coming back to Samson, when he came on the scene, Israel was under the yoke of the Philistines but God used Samson to free Israel and bring them out of their bondage. Moore (1895) reminds us of customs from Graeco-Roman culture having an echo in Samson's story: "Among the Greeks and Romans, being put to work at the mill was a not uncommon and much-dreaded punishment of slaves, to which there are many references in comic poets. Free men were also punished in this way for slight offences". Thus, perhaps God allowed Samson to suffer due to his iniquity later in life (Klein 1988; 1993). The books of Samuel indicate that the final suppression of the Philistines materialized under the leadership of King Saul and then mainly under King David. The two kings of Israel would essentially end what Samson had started. King Saul should be understood as reproducing and continuing Samson's fight against the Philistines as is apparent from the correspondences between the portrayals of both the kings (O'Connell, 1996). When Israel set foot on their new native land, they were ordered to destroy all traces of idolatry, that had defiled them (Leviticus 18:24-25, 27). The book of Judges tells us that "In those days there was no king in Israel. Everyone did what was right in his own eyes" (Judges 17:6). Clearly what Moses had advised was unheeded: "You shall not do according to all that we are doing here today, everyone doing whatever is right in his own eyes" (Deuteronomy 12:8).

\section{Human fallibility}

We all have our Achilles' heel. We all possess those areas of life in which we are vulnerable to attack. We all possess that area of our walk with God in which we are prone to fail. The writer of Hebrews calls it "the sin which doth so easily beset us" (Hebrews 12:1). That sin varies from person to person, but whatever that sin is in one's life, is your Achilles heel. Samson's complex personality is reflected in the fact that he is the only judge who participates in numerous feats (Greenstein, 1981). For Samson, his Achilles' heel was women and illegitimate sexual relationships. For others it might be the quest for money, fame, popularity, position, ambition, or power. For some it might be pride, lust, selfishness, idle-talk, anger, malice, or a host of other sins. Whatever that "besetting sin" might be for you, if you are not able to overcome it through the power of the Holy Spirit, it will be your downfall (The Sermon Notebook, n.d.). Samson was either a hero or a fool of the highest order (MacDonald, 2015). The story alerts us to why we need to be righteous and that sin holds power over people and consequently we need to be ever vigilant and aware of sin's existence and its likely control over our lives. One moment of feebleness can cause us to fall back into degrading sinful habits we supposed were gone forever (1 Peter 5:8).

\section{Samson and his Defilement - a parallel with Jesus}

After we read about Samson's transitory relationship with his Philistine wife and with a prostitute, we are informed that "After this he loved a woman in the Valley of Sorek, whose name was Delilah" (Judges 16:4). Greenstein avers that "The Samson narrative exemplifies Samson's attraction for the alien culture by portraying his unabating interest in Philistine women, one of them significantly a whore (Judges 16:1). This choice of motif, used only of Samson among the Israelite judges, cannot fail but allude to its latent reference, Israelite apostasy".

She forces him to reveal the secret to his great strength. He lies to her three times, (like Peter not acknowledging Jesus three times) and she says, "How can you say, 'I love you,' when your heart is not with me? You have mocked me these three times, and you have not told me where your great strength lies" (Judges 16:15). Samson's worship of women, and especially Delilah, has made him frailer than ever before, and he is spiritually blinded and he tells her his secret. Delilah communicates this knowledge to the Philistines and, after she cuts his hair, "his strength left him" and then, "the Philistines seized him and gouged out his eyes and brought him down to Gaza and bound him with bronze shackles" (Judges 16:19, 21). Caesarius of 
Arles understood Samson's death as anticipating the crucifixion of Jesus Christ (Newsome, Ringe \& Lapsley, 2012).

The Philistine leaders gather in a temple for their religious sacrifice to their false god Dagon, for having delivered Samson into their hands and the call for Samson so that all the people gathered can watch him execute feats of strength to amuse them all, about 3,000 people (Judges 16:27) Samson is led to them and he requests his captors to let him lean against the supporting pillars of the temple so as to rest. His strength was however regained as his hair grew while he was imprisoned (Judges 16:22). He prays for strength and "called to the Lord and said, 'Oh Lord God, please remember me and please strengthen me only this once, $\mathrm{O}$ God" (Judges 16:28). God gives him strength and he pushes against the pillars, causing the roof of the temple to tumble, crushing everybody below. Samson had incredible strength according to various passages in Judges (see Judges 14:19, 14:6, 15:12-15, 16:3, 16:29-30). But then he also had various weaknesses, nevertheless irrespective God used him.

The weaknesses which plagued him were his constant instinctive action without forethought demonstrating his foolish nature at times. Samson was clearly not an astute man who and he failed to consider the consequence of his actions. He lived for the present and he did not look to God for assistance or understanding, thus relying on his own strength and egotistical will. In addition, he was a very lustful individual (See Judges 14: 9, 14:2-3, 7). Covetousness overwhelmed Samson most of his life. He lived for the now moments and pleasing his weak flesh. Samson's consumption of honey, the marrying of a foreign unbeliever, going into the harlot, and then of course Delilah, show us his reckless nature. His spouse was not at all godly and instigated continued spiritual discomfort and caused him great distress. His riddle was guessed and the secret to his strength was evident due to his lustful nature (McKenzie, 1966; Bronner, 1993).

He did however also have numerous positive strengths such as his faith at certain times. He could at times perform mighty acts due to his faith and then the Spirit of the Lord would come upon him (Judges 15:18-19). At the end of his life, while a prisoner, he demonstrated his faith. Despite being debilitated and having his eyes gouged out, he turned to God and because of his great faith accomplished a great feat (Judges 15:28). The examples of his heroic strength related deeds are all found in Judges in the stories showing us his bravery. Samson was without any doubt a very courageous human being. He single-handedly clashed with a whole nation and freed his country. He was not averse to fighting against any amount of people because he knew the Lord was with him. He, like many of the saints, ultimately gave his life fighting God's battle (Hebrews 11:32, 34).

Greenstein (1981) asserts that "With all its anomalies and surprises, the narrative of Samson teases the reader to figure out the sense of the tale". There are certain Christian commentators who perceive Samson to be a type of Jesus Christ figure, based on parallels between Samson's story and the life of Jesus. Samson dies while conquering God's enemies just as Jesus died a physical death to liberate us from evil. When Jesus was introduced by the Archangel Gabriel we read "Behold, you will conceive in your womb and bear a son, and you shall call his name Jesus" (Luke 1:31). While the first angel told Samson's parents that he would "begin to save Israel from the hand of the Philistines" (Judges 13:5), Archangel Gabriel told Jesus's parents that "he will save his people from their sins" (Matthew 1:21). Samson's mother miraculously conceived through her husband, but Jesus's mother, Mary, conceived as a pure virgin. Even though both had angels announce the births, only Jesus had an assembly of angels singing for joy (Luke 2:13-14). Jesus, just like Samson, was publicly exhibited for his enemies to mock. However unlike Samson, Jesus walked into his death with complete willingness and unblemished innocence. And he didn't stay in the grave, whereas Samson died under the pile of rubble his actions created. 


\section{Why the fall of Samson?}

Numerous fundamentals are involved in Samson's fall. (The Sermon Notebook, n.d.). Firstly, "Then Samson went to Gaza" which was a Philistine city. There existed a pentapolis consisting of Gaza, Ashkelon, Ashdod, Gath, and Ekron which were collectively known as Philistia, or the Land of the Philistines. It was from this label that the whole country was later called Palestine by the Greeks. This was an important, strategic, commercial and military crossroads adjacent to the Mediterranean Sea and situated on the main road that allowed travel between Egypt, Babylon and Assyria. The name "Gaza" means "strength" and it was an important Philistine stronghold. It was a place recognized for its wickedness and idol worship. We are warned in Proverbs 4:14-15 where it says, "Enter not into the path of the wicked, and go not in the way of evil men. Avoid it, pass not by it, turn from it, and pass away."

Samson emulated Lot in a sense. We read in 2 Peter 2:8, "For that righteous man dwelling among them, in seeing and hearing, vexed his righteous soul from day to day with their unlawful deed" Lot placed himself and his family directly in the line of wickedness by moving them all to Sodom. He then paid a very high price for his iniquities (Gunn, 2005) just as Samson did. In Gaza, Samson "saw there a harlot" and he cast his gaze on the wrong things and it led him into iniquity. Klein (1993) suggests that, if we consider Delilah from a Philistine point of view she may indeed be viewed as "a resourceful woman, possibly a heroine to her own people, who perpetrates an age-old and repugnant ruse: using a man's love to bring him down". We can be defiled by the things we perceive (Matthew 5:28). Men such as Samson, Judah, David and Solomon were all led off into iniquity by the things they beheld. We are admonished in many scriptures to guard our eyes from the things that would defile us. For example, we read "Turn away mine eyes from beholding vanity; and quicken thou me in thy way," (Psalms 119:37). "I made a covenant with mine eyes; why then should I think upon a maid?" (Job 31:1) "Let thine eyes look right on, and let thine eyelids look straight before thee. Ponder the path of thy feet, and let all thy ways be established. Turn Neither to the right hand nor to the left: remove thy foot from evil" (Proverbs 4:25-27).

Samson could not resist Delilah and "went in unto her" and was in the wrong place, looking at the wrong things (Crenshaw, 1978). He thus contributed to his own downfall. James warns us that we should not allow ourselves to go to the wrong places and look at the wrong things (James 1:13-15) or we risk falling heavily (see Proverbs 16:18; 1 Corinthians 10:12). Proverbs 22:24-25 further alerts us, "Make no friendship with an angry man; and with a furious man thou shalt not go: Lest thou learn his ways, and get a snare to thy soul." Also, 1 Corinthians 15:33 declares, "Be not deceived: evil communications corrupt good manners." Ultimately Samson, while in the company of Delilah, is discovered by his adversaries who set a trap to apprehend him. Samson supposed he would turn aside for a few moments of pleasure in an illicit sexual relationship and have his fun and then simply just leave town. He did not believe he would be captured (Bronner, 1993) But the Philistines "compassed him in". They surrounded him after they laid a trap for his seizure (Niditch, 2008). Paul advises us that a life of wickedness is not a life of liberty and reckless abandon but rather it is a life of deep bondage and slavery (Ephesians 2:2-3). The Philistines just patiently "laid wait for him all night". Eventually all sinners will pay terrible price for falling into sin's trap (Galatians 6:7). Iniquity is cunning and we are called to take whatsoever steps are essential to circumvent it. If sinners knew what was waiting for them at the end of a life of iniquity, they would never take the first step along that path (see Proverbs 16:25; Matthew 7:13-14). The Philistines said "when it is day, we shall kill him" and laid their trap. However, the wages of sin amount to death (Romans 6:23; James $1: 15)$. 


\section{Lessons from Samson's story}

The Philistines have laid their trap but God delivered Samson from his adversaries. He awoke, and went out and took the gates of the city and carried them away super-humanly to "the top of the hill that is before Hebron." Samson was delivered by the grace of God despite the fact that he deserved judgement and reprimand for his guilt of what Jude 4 calls "turning the grace of God into lasciviousness."

The 1949 biblical film by Paramount pictures, Samson and Delilah, directed by Cecil B. DeMille and starring Victor Mature and Hedy Lamarr, was widely acclaimed by critics and turn out to be the highest-grossing film of 1950, winning two Academy Awards. In this film Samson is stereotypically portrayed as "handsome but dumb hulk of muscle" (Variety, 1949). Irrespective of muscles or not, God can use anybody to serve Him (Baker, 2016). Even though Samson was a lustful individual, he did believe in and serve God who used him in a mighty way (Shamase, 2021). Nevertheless, despite his great faith he could not overcome the enticements around him and he fell into sin. Christians believe that lust is used by Satan to bring down leaders and men and women of faith. God warns all believers of this repeatedly and we would be wise to distance ourselves from all temptations (2 Timothy 2:22). If Christians marry unbelievers, they are yoking with persons who will bring them bad consequences. Nonetheless, God watches over His people and carries out His plans. While Israel was enslaved to the Philistine yoke, God still opted to use Samson, a sinner, to liberate them.

\section{Conclusions}

The Philistines brought Samson out to make a mockery of him but he prayed for a moment of strength and pushed the pillars down, committing suicide and killing more than 3000 Philistines (Judges 16:26-30). In the same way, the story exemplifies the deliverance of Israel from her enemies. The story is somewhat allegorical and it epitomizes Israel's historical trajectory. The story can be understood on its narrative basis at a time when Judges ruled the land, or it can be viewed as a highly symbolic Israelite myth. Either way, it offers a strong spiritual message (Kurtz, 2018). God had a clear plan for Samson to liberate his people (Judges 13:5). Samson became a failure. Instead of bringing honour to God, his apostasy brought him dishonour. God instructed his people not to marry people from other nations. Samson repudiated the instruction (Judges 14:1-3). People seek materialism and worldliness and refuse to accept the control of God's word and stray from His directions. The Timnite woman and also the other two Philistine women with whom Samson associated, shows us the extent of his apostasy. The latent meaning of the Samson saga exposes the regressing of Israel and the need for atonement. If Samson teaches us anything, he teaches us the truth that we must guard our hearts. We must shield our lives from all the evil influences that would lead us away from God. Watch the places you go to and what you do. Watch the things you give you attention to. Watch the people you associate with. Keep yourself and your family strong and spiritual in all dealings (Smith, 2005). Although Samson spent his life chasing after other gods, he eventually recognized the source of his strength: "God ... please strengthen me," and he became strong again (Judges 16:28).

Samson's story is a aide-memoire that our true strength and hope is found only in the Lord Jesus Christ. Samson is referred to by Paul in Hebrews as an illustration of those who "through faith . . were made strong out of weakness" (Hebrews 11:33-34). In the same way, all people who recognize their weakness and place their hope and trust in Jesus will be saved, and will find their strength reinstated. When Samson had the Spirit of God upon him (Judges 13:25; $14: 6,19 ; 15: 14)$, he was an impressive and authoritative man with paranormal strength. However, notwithstanding his having the Spirit of the Lord upon him, his sexual desires of the flesh took hold of his life (1 John 2:16). He was gutsy before men but feeble when it came to women (see Proverbs 5:3; 6:32; Matthew 5:28). The more we permit ourselves to be 
predisposed to the solicitation of sin, the more blind we become. Samson was spiritually blind way before his eyes were gouged out plunging him into physical darkness (Judges 16:21). God can in every situation clearly use the wicked as well as the virtuous to achieve His Divine will.

Another message of the Samson saga, is that the procedure of building a godly household commences with a dedicated marriage (Smith, 2005). It could be argued that the faith of Israel was so compromised that marriage to a Philistine was generally considered to be a cultural issue rather than an issue of religious separation (Smith, 2005). Mobley views Samson as a "liminal hero" and such an slant accepts the dynamic to which Judges 14:4 points i.e. that It was by no means apparent that Israelites and Philistines were and would endure as diverse groups. Samson is thus seen as an instrument for separation to prevent absorption (Mobley, 2006). In spite of Samson's weaknesses, he did turn back to God before he died (Judges 16:28-30). Samson's family buried Samson between Zorah and Eshtaol at the tomb of his father Manoah, thus demonstrating some reconciliation between the family and Samson (Webb, 2012). God thus always provides opportunity for atonement and His grace is great. He never refuses to receive us but our part is to ask for forgiveness for our many transgressions. God thus rather exonerates than judges one, and in His divine dominion He used Samson to accomplish His purpose.

\section{References}

Baker, R. (2016). Hollow Men, Strange Women - Riddles, Codes and Otherness in the Book of Judges. Biblical Interpretation Series 143, Leiden: Brill.

Bar, S. (2020). The Death of Samson. Old Testament Essays, 33(1), 162-174. \{Available online at https://dx.doi.org/10.17159/2312-3621/2020/v33n1a10]

Bronner, L. L. (1993). Valorized or Vilified? The Women of Judges in Midrashic in Brenner (ed.), A Feminist Companion to Judges, Sheffield: JSOT, pp. 72-95.

Burgess, J.S. (2009). The Death and Afterlife of Achilles, Baltimore: Johns Hopkins University Press.

Burney, C.F. (1930). The book of Judges., $2 d$ ed., 3rd impression, London : Rivingtons.

Comay, J. \& Brownrigg, R. (1993). Who's Who in the Bible: The Old Testament and the Apocrypha, The New Testament, New York: Wing Books.

Crenshaw, J. L. (1978). Samson: A Secret Betrayed, A Vow Ignored, Atlanta: John Knox.

Crossan, J.D. (1968). Judges, The Jerome Biblical Commentary, Englewood Cliffs: PrenticeHall.

Graves, R. (2017). The Greek Myths: The Complete and Definitive Edition, Penguin Books Limited.

Greenstein, E. L. (1981). The Riddle of Samson, September 1981, Indiana University Press, 1(3), 237-260 [Available online at https://www.jstor.org/stable/20689009]

Gunn, D. M. (2005). Judges. Blackwell Bible Commentaries, Oxford: Blackwell.

Holy Bible, English Standard Version, New Living Translation, Revised English Bible, King James.

Klein, L. R. (1988). The Triumph of Irony in the Book of Judges, Sheffield: Almond, pp. 128132. 
Klein, L. R. (1993). 'The Book of Judges: Paradigm and Deviation in Images of Women', in A. Brenner (ed.), A Feminist Companion to Judges, Sheffield Academic Press, pp. 55-71.

Kurtz, P. (2018). Of Lions, Arabs \& Israelites: Some Lessons from the Samson Story for Writing the History of Biblical Scholarship. Journal of the Bible and its Reception, 5(1), 3148. [Available online at https://doi.org/10.1515/jbr-2016-0029]

Leviton, R. (2014). The Mertowney Mountain Interviews, iUniverse. p. 244.

MacDonald, N. (2015). Samson: Hero or Fool? The Many Faces of Samson, Edited by Erik Eynikel and Tobias Nicklas, The Journal of Theological Studies, 66(2), 696-698, [Available online at https://doi.org/10.1093/jts/flv107]

Margalith, O. (1987). The Legends of Samson / Heracles, Vetus Testamentum, 37(1-4), 6370 .

Matthews, V. H. (1989). Freedom and Entrapment in the Samson Narrative: a Literary Analysis., Perspectives in Religious Studies, 16(3), 245-257.

McKenzie, J. L. (1966). Samson, Dictionary of the Bible, Chicago: Bruce.

Mobley, G. (2006). Samson and the Liminal Hero in the Ancient Near East, New York: T \& T Clark.

Moore, G. F. (1895). A Critical and Exegetical Commentary on Judges, New York: Charles Scribner's sons.

Newsome, C-A., Ringe, S. H. \& Lapsley, J. E., eds. (2012). Women's Bible Commentary (3rd ed.), Louisville, KY: Westminster John Knox Press. p. 139

Niditch, S. (2008). Judges: A Commentary. Old Testament Library, Louisville: Westminster John Knox.

O'Connell, R. H. (1996). The Rhetoric of the Book of Judges, Leiden: Brill, pp. 295-296.

Shamase, M.Z. (2021). The Tragic Tale of a Giant, Lessons from Samson and Delilah, Inqanawe Publishers: Kwadlangezwa, South Africa.

Singer, I. et al., eds. (1901-1906). "Samson", The Jewish Encyclopedia, New York: Funk \& Wagnalls.

Smith, M, J. (2005). "The Failure of the Family in Judges, Part 2: Samson". SOR Faculty Publications and Presentations. 116. [Available online at https://digitalcommons.liberty.edu/sor_fac_pubs/116]

The Sermon Notebook, n.d.) Biblical Sources for Preachers and Teachers of the Word of God [Available online at https://www.sermonnotebook.org/judges/Judges\%2021\%20\%20Judges\%2016_1-3.htm]

Thomson, E. (1838). Prophecy, Types, And Miracles, The Great Bulwarks of Christianity: Or A Critical Examination and Demonstration of Some of The Evidences by which the Christian Faith Is Supported, Hatchard \& Son, p. 299-300.

Variety staff (31 December 1949). "Variety - Review: Samson and Delilah". Variety. [Available online at https://variety.com/1949/film/reviews/samson-and-delilah-1200416600/]

Webb, B. G. (2012). The Book of Judges, Grand Rapids, Michigan: William B. Eerdmans. 
Pharos Journal of Theology ISSN 2414-3324 online Volume 102 - (2021)

Copyright: @2021 Open Access/Author/s - Online @ http//: www.pharosjot.com

Zakovitch, Y. (1975). 'The Sacrifice of Gideon (Judges 6:11-24) and the Sacrifice of Manoah (Jude 13) Shnaton 1, 151-54. 